\title{
The development of a united ECEC workforce in New Zealand and England: a long, slow and fitful journey
}

\section{Claire Cameron, Carmen Dalli and Antonia Simon}

\begin{abstract}
A united child care and education workforce serving children under school age has many benefits but despite long held recognition of its advantages, progress towards this goal has been slow in many countries. This chapter traces policy trajectories towards, and away from, workforce integration in two countries, New Zealand and England, over the period 1986 2016. It takes three illustrative examples: workforce models, sector voices, and home-based ECEC, to document the complexities and tensions within integrationist shifts in early childhood education and care. New Zealand has made greater progress towards integration than England; nonetheless, sustaining unity is fragile.
\end{abstract}

Key words: New Zealand, England, Care, Education, unions, occupational models, integration, split workforces, family day care

\section{Introduction}

Professionalization of the ECEC workforce in both New Zealand (NZ) ${ }^{\mathrm{i}}$ and England has been a longstanding policy concern (e.g., Dalli \& Urban, 2010; Miller \& Cable, 2008). One developmental trajectory has been efforts to unite the 'care' and 'education' workforce conceptually, administratively and in practice. In NZ this began in the 1980s (Meade \& Podmore, 2002) and in England from 1997. A united care and education workforce is associated with benefits such as conceptual coherence, integrated curricula, more access to services for younger children, and a levelling of historic inequity between care and education workers. In six case studies of ECEC integration, all reported positive results (Kaga, Bennett and Moss 2010).

This chapter traces the different policy trajectories of ECEC workforce development in NZ and England. After setting out some issues in common we use current workforce data to illustrate the impact of policy in the two countries. We then focus on three illustrative issues 
to examine: i) the complexities of uniting workforce models of the 'new teacher' in NZ and the (now deleted) 'early years professional' in England; ii) the pay and conditions of work of the ECEC workforce in the two countries; and iii) home-based ECEC, called family day care in New Zealand and childminding in England.

Drawing on what we call 'sector voices' we track the impact of political advocacy, union activism and eventual conservative backlash in creating the current profile of the ECEC workforce in each country to evaluate the extent to which a truly united workforce has been achieved. We argue that despite major steps forward through qualifications and, in some instances, pay, historical tensions about the relationship between care and education continue to take their toll on the ambition of a wholly professionalised workforce in the ECEC sector.

Throughout the chapter we refer to the whole sector as early childhood education and care or ECEC, in keeping with OECD tradition and the dominant practice in NZ. Yet we are aware that this broad term covers a range of services whose names serve to indicate their historical origins and scope. ECEC includes 'childcare' such as day nurseries, childminders or family day care and playgroups or playcentres, as well as 'early education' services such as preschools, kindergartens and schools.

\section{A common heritage and integrationist policies}

In common with many other countries, both NZ and England had - until the late twentieth century - a split workforce based on a division between early education services for children aged three and over, supported by public funding, and services for children up to three years based on a model of care or 'minding' the children while parents worked. Typically, services for children under three received much less public funding, if any. The different services were associated with the priorities of different government departments (typically 'education' and 'welfare'); further differences have been noted related to 'access, regulation, funding and workforce, lead[ing] to problems of inequality and lack of continuity for children, parents and workers' (Kaga et al. 2010, p7; Kamerman, 2000).

Within NZ, the first formal step to integrate the childcare and preschool education workforce was taken on 1 July 1986 when, following years of lobbying by childcare activists, administrative and policy responsibility for childcare services was transferred from the Department of Social Welfare to the Department of Education (Meade \& Podmore, 2002). This break from the welfare principle as the driving force behind childcare policy was 
justified as a way to achieve 'equitable funding for childcare' (State Services Commission, 1980, p.91). It was also consistent with a growing consensus within the early childhood field that it was very difficult to separate care and education (e.g., Smith, 1988). As the integration of childcare policy and administration into the Department of Education was effected, a terminological shift also occurred in the official discourse with the terms 'childcare', 'daycare' and 'preschool' replaced by the more inclusive term 'early childhood education and care'.

The historical integration of childcare and preschool services at the policy level was followed in 1988 by the integration of the previously separate training pathways for work in childcare centres and kindergartens into one three-year early childhood teacher education diploma programme in Colleges of Education. The result was that by the end of 1990, new cohorts of early childhood teachers were graduating with a shared history of integrated study and practicum experiences gained across different ECEC settings. As these graduates took up positions in diverse parts of the sector, met at cross-sector conferences, and attended the same in-service professional learning courses, historical, philosophical and organisational boundaries started to dissolve and a new sense of sector unity emerged (Dalli, 2010). With the subsequent merger of Colleges of Education with university departments of education in the early 1990s, 3-year diploma level courses at Colleges of Education were phased out and replaced by a new 3-year Bachelor of Education degree, making early childhood teaching in NZ a graduate profession.

In the late 1980s, the ECEC sector was also included in widespread reforms of education aimed at creating a seamless education system. In the ECEC sector this led to the Before Five (Lange, 1988) policies which sought to remove long-standing funding inequities between previously called 'childcare' and 'preschool' services, and to improve quality and equity of access. These policies were widely welcomed (Meade, 1990) though short lived. In 1990, within months of the election of a neo-liberal government, the Before Five funding policies were dismantled leaving the integration of childcare administration under education, and the introduction of integrated training for work across the ECEC sector as the main policy achievements of the 1980s.

One of the strengths of the NZ ECEC sector is the mobilisation of the centre-based early childhood workforce into professional organisations and trade unions. In the early 1990s, union mergers strengthened the negotiating ability of the early childhood workforce. First, the 
Early Childhood Workers' Union and the Kindergarten Teachers' Union joined forces to become the Combined Early Childhood Union of Aotearoa New Zealand (CECUA), and, second, CECUA amalgamated with the primary school teachers' union, the NZ Educational Institute (NZEI) - Te Riu Roa. This strategic alliance was instrumental in facilitating a job sizing exercise between kindergarten and primary school teaching, resulting in a campaign for pay parity between them. Negotiated in 2002, pay parity for kindergarten teachers was later extended to all qualified early childhood (EC) teachers working in education and care centres - formerly called 'childcare'(May 2007).

As three-year integrated training for new ECEC teachers was becoming the norm, the need for coherent policies to upskill the existing early childhood workforce remained a key preoccupation throughout the 1990s (Early Childhood Group, 1994). An important development was the implementation of a point system (NZ Government, 1990) through which ECEC staff across the sector could have their very diverse training background, qualifications and experience evaluated by the New Zealand Qualifications Authority (NZQA). The point system provided a focus for the ECEC workforce and a means for assessing progress towards training goals; it also helped to identify the desirable elements in a 'benchmark' qualification for work in ECEC (NZQA, 1996; Meade \& Dalli, 1992).

The imperative for a benchmark qualification became more urgent with the launch of $T e$ Whäriki (Ministry of Education1996), the internationally acclaimed NZ early childhood curriculum. Simultaneous professional development initiatives to support implementation of the curriculum fostered the growing sense of workforce unity brought about by the integrated initial training and the union amalgamations. Slowly, but surely, a 'new teacher model' for ECEC work was taking shape.

The new teacher model was most fully articulated in the ten year strategic plan (SP) called Pathways to the Future: Ngā Huarahi Arataki (Ministry of Education, 2002), launched by the Labour-led coalition government elected in 1999. Building on sector recommendations, the SP set a goal that by 2012 all staff in 'teacher-led' early childhood services for $0-6$ year olds would be fully qualified and registered teachers with parity of pay with primary school teachers. Teacher-led services are services like kindergartens and education and care centres which are staffed by trained teachers. They are distinct from parent/whānau-led services like playcentres or ngā kōhanga reo - where family members are present alongside their children during the hours of operation. The qualification goal in the SP did not apply to these 
parent-led services. It also did not apply to home-based educators or caregivers who work directly with children. However, since home-based networks are co-ordinated by qualified teachers, and are part of the teacher-led part of the ECEC sector, the qualification requirement did apply to the home-based network co-ordinators. The implementation of the SP was brought to a premature halt by the election in 2008 of a conservative-led neo-liberal coalition government. Nonetheless, by then a major milestone had been achieved: the new ECEC teacher model was firmly in place in teacher-led ECEC settings.

In England, the story of integration started later and was one of stutter and stall rather than steady progression through streamlined policy. In 1997, the new Labour administration inherited a fragmented system of 'day care' and 'early education' that was largely ignored by policy and split between health and education departments. Over the preceding twenty years, child poverty and inequality had been rising with lone parents particularly likely to be at risk. At the same time, demand for full 'day care' was on the increase, principally among working mothers earning higher incomes (Moss 2014). Provision was inadequate to meet demand, and - apart from nursery schools and classes which employed teachers - staffed by low paid and low qualified 'care' workers with a confusing array of job titles (McGillivray 2008). The Labour Government advocated early childhood education and care services as a means to encourage parental (principally mothers') employment and so address child poverty. In three main ways, integration of care and education was pursued. First, in 1998, an important integrationist step was taken when governmental responsibility for ECEC was consolidated in one department, education, in the National Childcare Strategy. In 2007, local administrative areas (called local authorities) mirrored this step, establishing Departments of Children's Services. Second, an early years curriculum was introduced for all children attending ECEC services. First named (in 2000) as the Foundation Stage, the curriculum was for children aged three to the end of the first, reception, year in primary school (usually aged five). In 2008 this was extended to all children aged 0 - 5 and called the Early Years Foundation Stage (EYFS). The EYFS was clearly positioned within an 'educational' framework; it predefined early learning goals in areas of learning and development that were seen as 'useful for school' (Bennett 2006), and all care and education providers, regardless of their qualification or background, were expected to deliver it. In 2012, the EYFS was modified, and the number of learning goals reduced. But, as Moss (2014) points out, the focus on a narrow definition of education, mainly on literacy and numeracy, sharpened in this iteration, with an emphasis on the role of ECEC services in preparing children for school, or 'school readiness'. 
The third dimension of integration in English ECEC was that of regulation. In 2002, the schools inspection agency, Ofsted, adopted responsibility for regulating all childcare services (apart from nannies and au pairs who are employed by parents in their homes) as well as early childhood services in schools. All three dimensions of integration demonstrate a commitment to perceiving ECEC as 'education' services at a time when education was increasingly seen as driven by standards of academic performance. It was perhaps less 'integration' of care and education as subsumption of care under a schools agenda.

The introduction of Children's Centres by the Labour government (in 1998, when they were known as Sure Start local programmes) is an good example of working with concepts of integration in England. Building on earlier experience of combined centres, Children's Centres were envisaged as a universal neighbourhood service to cater for children of working and studying parents as well as supporting parents who needed additional help. By 2010, there were 3,500 children's centres in England. Their main role was to provide advice, guidance and support for parents, and, in the most deprived areas, to provide care and education sessions. At their best, children's centres brought together, under one roof, full day nursery education and childcare, with health and employment advice and support for parents. But, by 2010 , only 800 of the 3500 children's centres offered care and education places. They complemented, but did not replace, existing ECEC services.

However, in other respects, integration did not take place. The workforce, as we shall see in the next section, is still characterised by teachers working in school-based services and care workers (and others) in nurseries and in domestic premises. In contrast to NZ, there has been little integration of qualifications for those working with children under compulsory school age nor of sector strength derived from trade union organisation and membership. We discuss one integrationist occupational model, now discarded (and replaced), called the Early Years Professional, later in the chapter.

There have been shifts in government funding towards supporting parents with 'childcare' costs through tax credits towards the costs of paying fees for ECEC and entitlement to free 'childcare' for 30 hours per week for children aged three and four, and the most disadvantaged two-year olds (DfE 2015) in registered providers which can be schools, nurseries or other registered services. This entitlement is for children of employed parents, effectively subsidising childcare, not education and the arrangement still leaves many parents funding places themselves. Clearly, the terminology used in this financial support reflects a 
split between care and education rather than a united field of ECEC. At the time of writing, ministerial responsibility for 'childcare and early years' sits with the portfolio of the minister responsible for women and equalities, child poverty reduction, mental health services for children, school funding, and careers advice (DfE 2016). It is too early to tell what this will mean for the integration of the care and education agenda in EC services.

Overall, the story of integration of previously split early childhood workforce occupations in NZ and England can be illustrated through Tables 1 and 2 (below). Rather more progress towards integration can be seen in NZ in Table 1, which shows services designed for children of the entire preschool age range (rather than being split between older and younger age groups), and fewer occupational titles than in England.

\section{Table 1 about here}

In Table 2 we compare, so far as is possible, the size and characteristics of the ECEC workforce. Caution is needed in comparing England with NZ because of the way data sources compiled vary between the countries. For example, there is no adequate means of counting just those teachers working in early education settings in England, as all teachers in preschool services are counted within a category called 'primary and secondary teachers'. This leaves us with 'childcare' workers. Comparing this group with 'teachers' in NZ means including those working with rather different professional education backgrounds. In some cases it has been possible to make comparisons between workers in England and teachers and educators in NZ and these are given in Table 2. However, it is not possible to compare the two workforces on education levels: while in England it is possible to establish a 'highest level' of qualification, the discourse in $\mathrm{NZ}$ is rather different, with national statistics distinguishing between holders and non-holders of the benchmark qualification of a three-year diploma or undergraduate degree (see Table 2). Thus NZ statistics only show the proportion of qualified teachers within the total workforce and not the different levels of training.

\section{Table 2 about here}

There is a clear difference regarding qualifications between the two countries. There is missing data, as we know that almost all nursery and primary teachers in England have a relevant degree level qualification and a recognised teaching qualification but we do not know how many nursery teachers are in employment. Looking at the qualifications of English childcare workers (Table 2), we see a high proportion in the 'other' category (which includes 
school leaving and workplace based qualifications), and around a quarter have a post-school qualification including bachelor degrees. Among EC practitioners in NZ, at the end of 2013, over three-quarters $(76 \%)$ of staff in licensed teacher-led services held the benchmark qualification of a three year bachelor degree or diploma programme (Ministry of Education, 2014).

It is notable that as workforce integration has progressed in NZ, the points of crossover with English childcare workers have decreased. Childminders in England, for example, are largely self-employed with minimal requirements for keeping written policies or supervision (DfE 2014), although they must adhere to the early years curriculum. Home-based educators in NZ, by contrast, are members of local networks, and their practice is supervised and supported by Home-based Coordinators who hold a teaching qualification, making homebased ECEC a 'teacher-led' service. Arguably, the two roles, and expectations of them, are diverging. What is also clear, is that teachers in NZ, which include those working in services previously considered 'childcare', are older than childcare workers in England overall. While nearly all workers in both countries are female, there seems to be greater ethnic diversity among staff in NZ.

Clear differences between ECEC practitioners in England and NZ are visible when we examine pay. Table 3 sets out the annual income of childcare workers in the English Labour Force Survey and teachers in the NZ census for 2013 (Morrison, 2014).

\section{Table 3 about here}

Childcare workers are very low paid in England. Using Purchasing Power Parity (PPP) conversion, Table 3 shows that over half of childcare workers in England are earning less than $£ 10,000$ per annum (or \$NZ20,390, converted using PPP for 2013) compared with 22\% of the NZ ECE workforce. The low pay is in part explained by the high proportion of childcare workers in part-time employment (especially among playgroup workers, where the number of hours has declined sharply in the last ten years) (Simon, Owen and Hollingworth, 2016). Table 2 (above) shows that $41 \%$ of childcare workers in England work fewer than 29 hours compared with $28 \%$ of NZ ECE teachers. The overall low level of pay could also be explained by the young age profile of the English workforce (around a quarter of workers are under 24 years of age - see Table 1). This picture of low pay is supported by findings from a recent report by the UK's Low Pay Commission (2014): 41 per cent of the childcare workforce is paid less than $£ 7$ per hour (\$NZ14.27, converted using PPP for 2013). 
Figures presented here show some impact from the highly integrationist policies in NZ, compared to a rather more piecemeal approach in England. In both countries, however, there are complexities in uniting the ECEC workforce, illustrated below using three examples: the occupational models of the 'new teacher' in NZ and the Early Years Professional in England; the role of advocacy and unionisation in shaping integrationism; and the particular issue of childminders/family day carers and how they embody (or not) care and education.

\section{Uniting care and education through occupational models}

\section{The 'new teacher' in NZ}

As noted earlier, the ten-year Strategic Plan (SP), Pathways to the Future (Ministry of Education 2002), envisaged the 'early childhood teacher' as the main occupation working with young children in centre-based provision and co-ordinating home based networks. This was in contrast to the earlier separate roles of 'kindergarten teacher', 'childcare worker' and 'early childhood educator'.

The SP laid out target percentages of fully qualified and registered teachers to be achieved incrementally in teacher-led services over a ten-year period to 2012. The benchmark qualification was deemed to be a three-year diploma or undergraduate degree and could be acquired in a variety of ways. An array of qualifications, ranging from equivalency to a threeyear Diploma of Teaching through to four-year degrees and one-year graduate programmes was subsequently approved for registration with the NZ Teachers Council (renamed the Education Council in 2015). Teacher registration is achieved through successful completion of a post-qualification induction programme through which applicants are mentored by a registered teacher to meet registration criteria. Until this milestone is reached, newly qualified and employed teachers are called "provisionally registered teachers" diplomas. From 2011, primary school teaching qualifications also became acceptable for registration as an EC teacher.

Throughout the implementation of the SP this inclusive approach to qualification and registration was supported through a range of financial incentives including staff scholarships, higher funding rates for ECEC services meeting target levels of qualified staff; and loans and grants for students. However, in 2009, a new centre-right government elected just as the effects of the global financial crisis started to impact NZ, announced that it would no longer pursue the goal of $100 \%$ fully qualified teaching staff by 2012 and capped the top funding rate at the level of $80 \%$ qualified staff. Thus, from the budget of 2009-2010, the 
different funding streams - and those for other professional development initiatives - were withdrawn including for the flagship Centre of Innovation (COI) action research programme. The COI programme had created models of good practice which were disseminated nationally and internationally (Meade, 2010) with research teams recording the professional benefits of becoming teacher-researchers (e.g., Simmons et al., 2007). By 2009, when implementation of the strategic plan was prematurely halted, 20 teaching teams had been part of the COI programme and an unpublished evaluation of the programme was anecdotally reported to have documented extensive impact on improving sector morale and engagement with initiatives to enhance practice. Additionally, by 2010 the proportion of staff holding the recognised 'benchmark' teacher qualification had risen impressively to $66.8 \%$ of all staff in teacher-led services (Ministry of Education, 2014) compared to the 50.8\% figure in 2004 (Ministry of Education, 2014) with the biggest increase occurring amongst teachers working in education and care centres versus kindergartens- which had always been staffed by qualified teachers. The termination of the SP policies significantly slowed the momentum of change within the sector (Dalli, 2010). While the figures of qualified staff continued to rise over subsequent years to reach $74.6 \%$ of the workforce by 2014 , this $30.5 \%$ increase over 2004 figures (Ministry of Education, 2014) fell significantly short of the expectations of $100 \%$ qualified staff in teacher-led services by 2012. Many believed that with a sustained supportive policy infrastructure, the $100 \%$ target would have been achievable.

A concerning trend by 2014 was evidence that life as an early childhood teacher remained less lucrative than in other education sectors (Morrison, 2014). In a report which integrated 2013 national census data with workforce data gathered by the Ministry of Education, Morrison showed that only $25 \%$ of ECE teachers earn more than \$NZ50,000 ( $£ 24,522$, converted using PPP for 2013) compared to $39 \%$ of all employed adults, and $67 \%$ of school teachers. This suggests that despite progressive introduction since 2002, pay parity has not been wholly achieved for the ECEC sector. One likely consequence is that qualified EC teachers, particularly younger ones, will leave the sector. With the $80 \%$ qualified staff now seen as the new target, and with qualified staff making up 74.6\% of the ECEC workforce in teacher-led services (Ministry of Education, 2014), EC teachers are finding themselves working with less qualified staff on a more regular basis with concerns about rising workplace stress. One cannot expect qualified teachers to carry the responsibility for ensuring a quality experience for children and families by themselves (Meade et al. (2012). A recent survey of qualified EC staff found that despite increased professionalization through 
qualifications, EC teachers were experiencing a renewed sense of low societal esteem for their work and low occupational value (Dalli \& Cherrington, 2015; see also Kane and Mallon, 2006).

\section{The early years professional status}

The Early Years Professional Status (EYPS) in England was an attempt to build a graduate level occupational model that combined care and education with the equivalent status of qualified teachers. This is similar to its NZ counterpart, and the 'new teacher' was one model considered during consultation (DfES 2003), the other being the continental European social pedagogue. Introduced in 2007, by 2014, there were approximately 13,300 EYPs in England (Taylor 2014). The model arose 'out of thin air' (Moss 2008: 127), being neither the new all graduate teacher model nor the holistic model of pedagogue with applicability across children's services. But the need for a graduate status arose from influential research by Sylva et al. $(2003 ; 2010)$ linking the quality of ECEC provision with the quality of staff. The effect of high quality staff was particularly marked for the social and learning gains of children living in economically disadvantaged areas. Sylva et al. $(2003 ; 2010)$ had recommended there should be a high proportion of trained teachers, or equivalent, holding lead positions in ECEC settings in order to achieve good outcomes. Equivalence, however, was never defined. The EYP model sought to integrate care and education, to be applicable across the whole 0-5 year age range, and to be attractive to employers in the private, voluntary and independent (PVI) and public sector provision. Each setting was supposed to have a graduate or EYP and two in settings in areas of high levels of social disadvantage. Four routes to attaining the Status, dependent on prior experience and qualifications, were introduced taking 3 and 15 months to complete.

The EYP was to lead practice and be a change agent in the setting. Training was a collaboration between training providers, including universities and employers. The implementation of the EYP model was part of a wider investment in ECEC including a Transformation Fund, later superseded by a Graduate Leader Fund (GLF), as 'ring-fenced funding to support all full day care PVI sector providers in employing a graduate or Early Years Professional by 2015' (Mathers et al. 2012:12). The GLF was intended to support locally designed professional development. Outcomes were measured against the baseline of the number of graduates leading practice in PVI full day care settings in each area (Mathers et al. 2012). 
Overall, the EYP role brought significant gains to children's care and education, particularly those in the age range 30 months to five years. Mathers et al. (2012:6) found improvements in 'positive staff-child interactions; support for communication, language and literacy; reasoning/thinking skills and scientific understanding; provision of a developmentally appropriate schedule; and providing for individual needs and diversity'. The EYP was also often a catalyst for improvements to children's learning and structural changes such as a key worker systems or parental involvement. Fewer gains from EYP presence were noted in the quality of provision for younger children (birth to 30 months) (Mathers et al.2012).

There were professional development advantages from attaining EYP Status. Trainees noted increased professional confidence and new knowledge and skills (Hadfield et al. 2012; Roberts-Holmes 2013), particularly theoretical knowledge and its relationship to practice. However, qualified teachers felt the EYP training confirmed what they already knew and represented 'jumping through more hoops' (Roberts-Holmes 2013:345).

One intention of the EYP was that practitioners would be equipped to lead practice in the workplace and inspire other practitioners (CWDC 2010 cited in McDowell Clark 2012), through modelling good practice. Early studies indicated that the 'change agent' role was proving difficult (Simpson 2010), particularly for those not already in senior positions (Miller and Cameron 2010; McDowell Clark 2012). Most EYPs reported that holding the Status had improved their ability to carry out improvements in their settings, and that colleagues were more receptive to their ideas (Hadfield et al. 2013). McDowell Clark (2012) characterised the EYP role as exercising 'catalytic leadership' where the practitioner has influence but not authority. In theory, this accords with the position of teachers in terms of being free from financial, administrative and managerial demands to focus on pedagogical leadership (Roberts-Holmes 2012; Aubrey 2007). In practice, the roles of EYP and manager were often combined, particularly for those working in the PVI sector (Hadfield et al. 2013).

While the EYP Status did address pedagogical coherence, it did little in terms of workforce professionalization. There was a lack of parity with early childhood teachers, in terms of pay and conditions, and professional status. The EYP Status did not convey the Qualified Teacher Status that qualified teachers enjoyed. Despite the assertion of broad equivalence between the two Statuses they were in fact quite distinctive. Holders of the EYP Status are counted as part of the childcare workforce, which, as noted in Table 2 , is characterised by low salaries. In the PVI sector, salary is closely linked to the ability of parents to pay fees. Despite some tax 
credit subsidies, parents in England spend more of their net income on ECEC costs than in other OECD countries, meaning limited room for salary increases for the introduction of EYPS. Working as a graduate in the PVI ECEC sector meant earning little more than half the national (graduate and non-graduate) mean hourly wage for the UK (Brind et al. 2014). The EYP model threatened to 'ghettoise' EYPs in the lower paid private and voluntary sector (Hevey, 2007). With prescience, Hevey (2007) questioned the long term affordability of EYPs once initial government funding ended. In 2013, new occupational models were introduced and EYPs were replaced by Early Years Teachers. The latter were designed to be teaching 'specialists in early childhood development, trained to work with babies and young children'. They had to meet 'the same entry requirements as primary classroom trainee teacher' (DfE 2013, p27), and were supported by Early Years Educators, whose entry criteria were less stringent. These new models employed the terminology of education but were not accompanied by new measures to address unity across the care and education workforce. By May 2016, EYT training providers were closing courses due to lack of demand (Crown 2016).

\section{Union representation and professional advocacy in ECEC}

The second illustrative issue of workforce integration is collective action in the ECEC sector and, within NZ, the winning of pay parity for early childhood teachers with their primary school peers.

Unionism for NZ ECEC staff has a relatively short history with the first early childhood professional organisation, the Kindergarten Teachers' Association (KTA), established in 1952. In 1958, KTA was recognised as a service organisation able to enter into salary negotiations on behalf of its members. During the 1960s and 1970s, the rapid expansion of the kindergarten service saw the KTA become a significant political force with salaries and staffing as the key issues (Clark, Cook \& Pearson, 1983).

By contrast, unionisation of childcare workers did not start till 1982 with the setting up of the Early Childhood Workers' Union (ECWU) by a group of women activists building on 20 years of activism and lobbying to improve the training and public perception of childcare workers.

Clark et al. (1983) argued that without a common background of training, childcare workers typically had stronger relationships with the parents in their centre - who paid their wages - 
than with other childcare workers. But this close relationship with parents also made collective action to improve pay harder to achieve than for kindergarten teachers who had trained together, belonged to regional associations, and negotiated salaries with the Government. At the same time there was much in common, not least their female membership and common concern with care and education of children. Clark et al. (1983: 19) called for an 'effective forum for the debate over the values and beliefs surrounding the role of men and women, community and state, and their responsibility for child-rearing'. This was a strongly activist, feminist movement, concerned with advancing the cause of quality provision for children, and an enhanced status for early childhood work. In 1990, ECWU amalgamated with KTA to form the Combined Early Childhood Union of Aotearoa (CECUA). One KTA member, interviewed in 1994, recalled of this time:

What was emerging was a group of young women who were actually starting to look at the job as a profession and that was a key thing that started the change... We had to make political stands against the government of the day because of the appalling wages and our conditions of employment (reported in May, 1997, p.7)

The professional aspiration captured in this teacher's statement reflected the need to improve employment and pay conditions and was strongly connected to political action. The merger of CECUA with NZEI in 1994 laid the ground for this aspiration to take shape: By the end of the year NZEI had already published two reports to build the pay parity argument for both kindergarten teachers (NZEI, 1994a), and for early childhood “workers” (NZEI, 1994b).

Meanwhile, another campaign was brewing. In 1990 NZ had elected a New Right government that, within weeks, had dismantled many of the recently-introduced Before Five policies (Dalli, 1993; Meade \& Dalli, 1992). Under the guise of establishing funding equity across all services, this government also took away the funding base for kindergartens, and effectively privatised them (Davison 1997). By1995, the funding situation of kindergartens was so dire that NZEI mounted a 17-month campaign, marshalling parents to its cause, to reverse the government's privatisation policy and to increase kindergarten teachers' salaries. In this context, the pay parity issue receded from the public eye.

By the mid-90s the sector had lost trust in the New Right government's will to move forward the sector's integrationist agenda of ensuring quality across services. Apart from the erosion of the Before Five policies, and the attempt to privatise kindergartens, the sector was incensed 
that the results of a Ministry of Education-led national forum in 1994 - on the future of ECEC - were ignored. In response, the NZEI set up a working party to develop a statement of what the ECEC sector wanted for the future resulting in a policy blueprint entitled Future Directions (New Zealand Educational Institute, 1996). The report was well received by political parties beyond government and eventually became the basis of Labour's 1999 preelection manifesto (Wells, 1999). A key recommendation was that 'government establish a working group to progress work on a unified teaching pay scale and pay parity for early childhood teachers' (Early Childhood Education Project, 1996, p24). In 2002, armed with an NZEI-commissioned pay comparison of the work of kindergarten teachers against that of primary teachers (Burns, 1999), NZEI secured a government commitment to set up a ministerial working group to establish benchmarks for pay parity of kindergarten teachers with school teachers and to recommend implementation (May, 2007; Mitchell, 2002). In a memorable statement at an early childhood conference in 2005 , the then minister of education, Trevor Mallard, stated: 'Early childhood people are being regarded as professionals. They have gone from 'childcarer' to 'educator'. This was the debate of the 70s' (Mallard, 2005).

At the time of writing, NZEI remains the only industrial union acting on behalf of early childhood teachers in salary negotiations, across 17 types of employment agreements. Its current membership includes 4782 early childhood staff, or $22 \%$ of all qualified and registered early childhood teachers (see Table 4).

Table 4 about here

Significantly, Table 4 shows that kindergarten teachers are the most highly unionised with approximately $71 \%$ of kindergarten teachers belonging to NZEI; by comparison only $12.5 \%$ of all other ECEC qualified and registered teachers contribute to the total ECEC membership. This raises the question of whether the goals of amalgamation in the late 1980s and 1990s have truly been achieved. An NZEI paper written in the late 1990s described the amalgamation as the result of workers recognising the need 'to hold together collectively to fend off the new right agenda' (NZEI, undated, p.4). However, with the non-kindergarten part of the sector being the fastest growing, but having the smallest representation within the ECEC industrial union, it would appear that the new right agenda is once again on the ascendant. 
Union activism in $\mathrm{NZ}$ is a story of commitment to goals of quality services and equality for members across several decades. Creating a single union and pay parity across the sector are arguably integrationist causes. By contrast, few childcare workers in England are members of trade unions or professional associations despite a long history of organisational presence. Early professional associations reflected the conceptual split between care and education. Different rationales for types of service underscored the evolution of different sector voices throughout the twentieth century (Penn 2009). The National Society of Day Nurseries, founded in 1906, existed to define and improve the quality of care for young children while their mothers worked. On the other hand, the Nursery Schools Association was founded, in 1923 , for the purposes of promoting fully qualified teachers with specialist training as appropriate staffing for young children of nursery school age (then 2-7 years).

However, advocacy organisations have been influential in shaping the development of ECEC. In the 1960s, the Preschool Playgroups Association (now the Pre-School Learning Alliance) campaigned for part-time, parent-run sessional services to compensate for the lack of early educational opportunities in many areas of the country. Playgroups largely supported middle class non-working mothers, and did little to support the childcare needs of poor and minority ethnic mothers, who were more likely to be employed (Penn 2009). The prevailing ideology, on which playgroups thrived, was that mothers should stay at home with their young children until they started school. This was challenged, from 1980, by the feminist inspired National Child Care Campaign (NCCC), which argued that mothers, fathers and children would benefit from 'Childcare for All' that combined education and care, staffed by well-trained workers in community nurseries. With some government funding in place, the NCCC spawned the Day Care Trust which ran community nurseries and campaigned on 'day care' issues. It remains an important voice for the sector. In 2015, the (now) Family and Day Care Trust (FDCT) and the Pre-School Learning Alliance (PLA) challenged the government's planned extension of the hours of free childcare available from 16 to 30 on the grounds of financial viability for providers, particularly those in the PVI sector. They argued that government funding did not cover the cost of providing the care, and parents and providers were left to make up the shortfall. The FDCT pointed out that while parents in England already pay higher fees than their counterparts in other European countries, providers find it difficult to cover their costs. Furthermore, in a long running theme of differential provision for different families, the FDCT argued, in early 2016, that while ECEC can act as a protective factor against the negative effects of poverty, it is currently failing to reach its 
potential as the distribution of services is 'less favourable to families in less prosperous areas ... childcare in the least affluent areas is dominated by (state financed) providers in schools, the majority of which do not offer daycare, supported by a limited patchwork of voluntary services and childminders. Families therefore often lack access to year-round, flexible daycare' (Butler and Rutter 2016, p 4).

The PLA and the FDCT are just two examples of advocacy organisations across the ECEC field. There is also BAECE (the British Association for Early Childhood Education), now Early Learning, and the National Childminding Association, now PACEY (the Professional Association for Childcare and Early Years). What is notable is that the terminology employed often retains the division of 'daycare', 'care' and 'education'. This may reflect long held claims to separate parts of the ECEC workforce for membership recruitment purposes or it may speak to a policy agenda that has still not adopted the internationally agreed nomenclature of ECEC. Government policy, for example, still refers to 'more great childcare' and the 'childcare offer'.

While there are numerous sector voices, Moss et al. (2004) pointed out that the main teaching unions restrict membership to graduate teachers, and emphasise the superior position of teachers within the care and education workforce. This is in striking contrast to the feminist inspired NZ rallying cry of unity across the sector. Given the qualification profile of the workforce, the teacher unions' position makes creating a single sector voice for ECEC in England more or less impossible and inhibits the development of a strong union voice. Actual membership of unions or professional associations is not extensive. PACEY has around 30,000 members, mostly childminders, while Early Education has about 3,500 individual members. One trade union approached to request this information refused to reveal it. Overall, Table 5 shows that nearly ten percent of 'childcare' workers (i.e., nursery nurses and assistants, childminders and related occupations, and playworkers, so excluding early childhood teachers) in the Labour Force Survey ${ }^{\mathrm{ii}}$, are members of a trade union or staff association.

\section{Table 5 about here}

\section{Family day care: tensions over 'education', professionalization and integration}

Our third issue is that of family day care. Day care in domestic, familiar settings is a wellestablished but in some ways atypical form of ECEC in both NZ and England. Indeed, in the drive towards professionalisation and educationally oriented services, it might be considered 
an outlier. Internationally and in NZ known as 'family day care', but as 'childminding' in England, this form of ECEC is both home-based and care-oriented in practice.

In England, there are around 100,000 childminders (see Table 2); and around 344,000 children have a childminder (DfE 2016, SFR 09). It is overwhelmingly (98\%) a female occupation, with low earnings ( $£ 11,400$ p.a on average, DfE 2013 - \$NZ23,245, converted using PPP for $2013^{\mathrm{iii}}$ ). The central concept defining childminding is an overarching domestic or 'care' setting within which 'educational' activities might take place. The domestic settings give rise to a longstanding association with mothering, since many childminders take up this work when their own children are young (Mooney et al. 2003; Everiss \& Dalli, 2003), and there are no pre-entry requirements that might mitigate, depart from, or adapt the value of the mothering experience in caring for non-related children. These features speak to an established conceptual division between care and education that is arguably not overcome by the adoption of family day care within integrated early education in either England or NZ.

Since 1998 there have been sustained attempts to draw childminders in England into a largely 'educational' framework. Kalitowski (2016) reports that childminders have made 'great strides' in terms of both quality ( $84 \%$ are now rated 'good' or 'outstanding' by the national inspection agency, Ofsted) and qualifications, since two thirds of registered childminders have a Level 3 award (equivalent to a school leaving qualification at age 18 and sufficient for working unsupervised with children). Training is not mandatory, however. Qualifications are seen as a proxy for 'high quality pedagogic environments' that ensure 'practitioners involve children, simulate interactions with and between children and use diverse scaffolding strategies such as guiding, modelling and questioning. [Practitioners should be engaging children] in meaningful activities that promote their conceptual understanding of the world and [helping to] construct positive adult-child relationships' (Kalitwoski 2016: 4). The argument that only high quality environments help children to make significant progress foregrounds educational objectives for childminding.

For children under three, often seen as a particularly suitable age group for childminding (Vincent and Ball, 2006), Mathers et al. (2014) found that four key criteria around i) interaction with sensitive and responsive adults, ii) play where children can take the lead, iii) support for communication and language, and iv) being physically active, were most likely to support high quality experiences for children. Graduate level trained teachers are a critical ingredient in high quality early years settings (Sylva et al. 2004) and for childminders who 
support disadvantaged two year olds, access to support from a graduate level trained educator/teacher, strengthened networks and interactions with group provision would be highly beneficial (Mathers et al. 2014; Siraj-Blatchford and Siraj-Blatchford 2010). In sum, recent research on the quality of early childhood settings, including childminding, foreground an educational, and developmental lens, rather than a 'care' one for both the adults and children. Since 'educational', in England, at least, is associated with formal settings, such as schools, and since one key lever for quality is inspection and registration, the regulatory environment is a main vehicle for insisting upon (educational) requirements. O'Connell (2011), however, argued that childminders quietly contest or even resist the 'technologies of quality' associated with inspections. In her study they: disagreed with the requirements or advice that they display posters in their homes; shared out recommended resources and brought them out just for inspection visits; regarded activity plans or timetables as overly formal given children's wishes and needs at any moment in time and believed that adopting the unfamiliar language in the new curriculum at the time (Birth to Three Matters) to be an unreliable indicator of high quality practice. These childminders identified primarily with a 'care' and family ethos and articulated a tension that is not new - between the formal trappings of 'work' in a regulated environment and the informal, familial and domestic environment of family and home (Mooney 2003). That childminders are less likely to be associated with 'education' is reflected in parental views that school based settings are more likely to be encouraging academic and social skills (Huskinson et al., 2016).

In the quest for integration under 'education', childminding or family day care - as currently organised on a largely individual, self-employed basis -seems to be limited. At a time when the English government is expanding 'free' childcare hours and relying on childminders to provide a proportion of these, especially to cover 'non-standard' working hours of parents, tensions around the concept of 'education' and 'care' endure. This may be partly due to the way 'education' is perceived as formal, documented, and evaluated. Another is the way childminders are conceptualised as autonomous and self-regulating.

Recent secondary analysis of large scale data sets suggests that numbers of childminders are decreasing, which might be related to poor awareness of regulatory requirements, and the increasing cost of registration; alternatively it could be related to a rise in illegal childminding, since more people describe themselves as childminders than are registered with Ofsted (Simon, Owen and Hollingworth 2015). 
By contrast, family day care - or home-based education and care (HBEC) - provision is growing in NZ. Between 2004 and 2014 the number of services rose by 6.6\%, with enrolment numbers in the same period almost doubling from 9,922 to 19,162 . This makes HBEC one of the fastest growing early childhood provisions, especially for children under two years, who make up 57.8\% of all HBEC enrolments (Ministry of Education, 2014). In NZ, HBEC is provided in familial homes as part of a co-ordinated teacher-led service and licensed under the provision of the Education (Early Childhood Services) Regulations 2008. These regulations specify an adult-to-child ratio of 1:4 children under the age of 6 years (in addition to any child enrolled at school who is the child of the person who provides the education or care). An informal and unregulated home-based sector also exists but remains hidden from the domain of public policy.

Some of the recent growth in HBEC services reflects the emergence of a diverse range of new providers, including kindergarten associations who have expanded to include running home-based EC networks under the oversight of their qualified and registered teachers, and au pair agencies who place (typically young) women wanting to travel and experience work life in NZ with a family needing a nanny. Thus, the contemporary NZ HBEC scene is very different to that in the 1970 s when the first home-based family day care services were established (St. Johanser, 1980).

Despite its recent growth, home-based or family day care remains largely neglected by researchers, not the least because of the difficulty of gaining access to the private space of domestic homes as a research site. This invisibility of HBEC provision to the public eye continues to reinforce the general perception that HBEC is primarily a custodial activity - a view shared also by parents (Education Review Office, 2009) - rather than a service that is simultaneously educational, which is the basis on which it is funded.

A commonly cited concern is that while most network co-ordinators are registered teachers, only a few home-based educators who are in direct contact with children and their families (3\% in 2013; see Ministry of Education, 2014) hold qualifications eligible for teacher registration. A government-led report to investigate issues in home based early childhood education was abandoned in 2013 leaving concerns about the quality and wise use of government resources in HBEC services unresolved (Early Childhood Council, 2013; Education Review Office, 2009; Smith, 2015). Such reports leave the HBEC sector in a very uncomfortable space. On the one hand the sector benefits from funding allocated for 
education and care services, while on the other hand, available evidence suggests that parts of the sector may be using government funding in ways that were not originally intended. Even providers which are teacher-led, have networks, and get good funding, continue to pay HB educators very little. This reinforces the historical image of family day care as a vocational care activity and maintains an uneasy equilibrium between care and domesticity on the one hand, and the education policy framework that funds it on the other.

\section{Conclusion}

The two integrationist trajectories documented in this chapter illustrate the critical role of both top-down government-led policy in defining and resourcing a vision for uniting the care and education workforces in ECEC, and the no less important and complementary role of bottom-up sector-led policy advocacy activity in stimulating visionary policy and responding to policy measures.

The chapter shows that ECEC policy in New Zealand - particularly that over the ten year period to 2010, coupled with energetic and focused early childhood sector specialist advocacy - has driven and sustained a transformation in the workforce towards conceptual coherence, graduate level qualifications and ongoing professional development as well as higher pay. While the goal of a fully graduate workforce has not yet been achieved, with $74.6 \%$ of its EC workforce in teacher-led services qualified at the benchmark level of a threeyear diploma or degree, NZ has the most professionalised early childhood workforce in the world. Comparisons on professionalization dimensions are clearly hampered by a lack of access to data specifically about early childhood education teachers in England; nonetheless, the direction of travel is clear. ECEC practitioners in England do not have access to a unified occupational model across the preschool age range and the policy activity towards integration has not specifically addressed the low pay for working in what is often, still, described in terms of 'childcare' and not a unified sector of early childhood education and care.

However, even within the comparatively 'good news' story of the NZ ECEC workforce, we also noted signs of retrenchment in policy and its impact since 2010. While the proportion of the workforce that holds a qualification is rising in both countries, pay has not kept pace and practitioners' sense of societal esteem for their work remains low. Collective action via unions might be a way forward but our analysis shows that the scope for this may be limited: in NZ and England membership rates are low and/or organisationally fragmented. Lastly, the 
sense of a conceptually unified workforce is challenged by home based early education. Numbers of home-based carers are falling in England but rising in NZ. In England, the rise of a (narrowly defined) educational framework for ECEC possibly disadvantages the (broadly defined) 'care' provided by childminders. In NZ, the educational framework is more broadly defined, but the care arrangements being operationalised within it give some cause for concern that a narrower understanding of care is being resurrected. The case for an integrated workforce is conceptually solid but the political and practical journey is long and often tortuous with shifting policy directions making progress fitful and fragile.

\section{References}

Bennett, J. (2006) Starting Strong II: Early Childhood Education and Care, Organisation for Economic Co-operation and Development, OECD Publishing

Butler, A. and Rutter, J. (2016). Creating an anti-poverty childcare system. Joseph Rowntree Foundation.

Burns, J. (1999). Kindergarten and primary teachers: a comparison of their work. Wellington. New Zealand Educational Institute (NZEI)- Te Riu Roa.

Clark, K., Cook, H., \& Pearson, J. (1983). Two models of unionism in early childhood education. The Kindergarten Teachers' Association and the Early Childhood Workers' Union. Paper presented at the $3^{\text {rd }}$ Early Childhood Convention, Ngaruawahia High School and Turangawaewae Marae. Proceedings, pp. 16-19. Hamilton. New Zealand.

Crown, H. (2016) Providers cut EYT courses due to low demand, Nursery World, 2 May.

Dalli, C. (1994). Is Cinderella back among the cinders? A review of early childhood education in the early 1990s. New Zealand Annual Review of Education,3:1992, 223-252.

Dalli, C. (2010). Towards the re-emergence of a critical ecology of the early childhood profession in New Zealand. Contemporary Issues in Early Childhood,11(1), 61-74.

Dalli C, Cherrington S.A, (2015). Notions of professionalism in early childhood practice: do we still think the same way? A ten-year follow-up study.Early Childhood Convention (Rotorua, 1 - 4 October 2015)

Dalli, C., \& Urban, M. (Eds.). (2010). Professionalism in early childhood education and care: International perspectives. London \& New York: Routledge 
Davison, C. (1997). The sinking of the early childhood education flagship? Government's plan to privatise kindergartens: the bulk-finding story. Wellington. Institute for Early

Childhood Studies, Occasional Paper 3. Victoria University of Wellington

Department of Education (1947). Report of the Consultative Committee on Pre-school

Educational Services. Wellington. Department of Education.

Department for Education (2015) Childcare Bill: Policy Statement.

https://www.gov.uk/government/uploads/system/uploads/attachment_data/file/482517/Childc are_Bill_Policy_Statement_12.03.2015.pdf

DfE 2016, SFR 09

DfE (2014) Statutory framework for the early years foundation stage Setting the standards for learning, development and care for children from birth to five, DfE,

https://www.gov.uk/government/uploads/system/uploads/attachment_data/file/335504/EYFS _framework_from_1_September_2014_with_clarification_note.pdf

Department for Education (2013) More Great Childcare: Raising quality and giving parents more choice available at:

https://www.gov.uk/government/uploads/system/uploads/attachment_data/file/219660/More 20Great_20Childcare_20v2.pdf, accessed 12 November 2016

Department for Education and Skills (2003) Children's Workforce Strategy: A strategy to build a world-class workforce for children and young people, DfES Publications, Nottingham Early Childhood Group (1994). Early Childhood Qualifications and Training: A summary of key developments. Independent report.

Early Childhood Council (2013). Supporting home-based ECE. https://www.ecc.org.nz/Story?Action=View\&Story_id=1087(Retrieved 26 August 2016)

Education (Early Childhood Services) Regulations 2008. (SR 2008/204)

http://www.legislation.govt.nz/regulation/public/2008/0204/latest/DLM1412635.html

Education Review Office (2009). The quality of education and care in home-based early childhood services. Early childhood monographs Wellington, New Zealand: Education Review Office. 
Everiss,E. (2000). From one home to another: What does research tell us about quality in home-based settings? Childrenz Issues: Journal of the Children's Issues Centre, 4(1), 32-35.

Everiss, E., \& Dalli, C. (2003). Family day care in New Zealand: Issues of professionalism, training and quality. In J. Statham \& A. Mooney (Eds.), Family day care: International perspectives on policy, practice and quality (pp. 59-77). London: Jessica Kingsley.

Harkness, C. (2004). Qualifications and registration in the early childhood education Teacher-led workforce. Sector overview and service type breakdown. Wellington, Ministry of Education

Hedges, H. 2007. Funds of knowledge in early childhood communities of inquiry. Unpublished $\mathrm{PhD}$ thesis, Massey University, Palmerston North. http://hdl.handle.net/10179/580

Huskinson, T., Hobden, S., Oliver, D., Keyes, J., Littlewood, M., Pye, J., and Tipping, S. (2016) Childcare and early years survey of parents 2014 to 2015, DfE

Insight Research (1992). Bulk Funding. A study of Public Attitudes. Wellington. Kaga, Y., Bennett, J. \& Moss, P. (2010). Caring and learning together. A cross-national study on the integration of early childhood care and education within education. Paris. UNESCO Kalitowski, S. (2016) Towards an Early Years Workforce Development Strategy for England, PACEY

Kamerman, S.B. (2000). Early childhood education and care: an overview of developments in the OECD countries. International Journal of Educational Research, 33, 7-29

Kane, R.\& Mallon,M., with Butler,P., Sullman, M., Godin-McKerras, L., \& Ward, R.(2006). Perceptions of teachers and teaching. Wellington. New Zealand Ministry of Education Lange, D. (1988). Before Five: Early childhood care and education in New Zealand. Wellington. Department of Education.

Low Pay Commission. (2014). National Minimum Wage. Low Pay Commission Report 2014. 
McGillivray, G. (2008). Nannies, nursery nurses and early years professionals: constructions of professional identity in the early years workforce in England, European Early Childhood Education Research Journal, 16:2, 242-254, DOI:

$10.1080 / 13502930802141659$

McLachlan, C.J., L. Carvalho, K. Kumar, and de N. Lautour. 2006. Emergent literacy in early childhood settings in New Zealand. Australian Journal of Early Childhood 31, no. 2: 31-41

Mallard, R. (2005). Ministerial address. National conference, Te Tari Puna Ora New Zealand Childcare Association, 15-17 July, Rotorua, New Zealand.

Mathers et al. (2014) S. Mathers, N. Eisenstadt, K. Sylva, E. Soukakou and K. Ereky-Stevens (2014), Sound Foundations: A Review of the Research Evidence on Quality of Early Childhood Education and Care for children Under Three (London: The Sutton Trust), www.suttontrust.com/researcharchive/sound-foundations/.

Maughan, C., Rutter J., and Butler, A. (2016). In for a pound. The relationship between staff wages and Ofsted grades in group-based childcare provision. Family and Childcare Trust.

May, H. (2001). Politics in the playground. Wellington. Bridget Williams Books \& New Zealand Council for Educational Research.

May, H. (1997). The Discovery of Early Childhood. Wellington: Auckland University Press / New Zealand Council for Educational Research.

May, H. (2007). 'Minding', 'working', 'teaching': Childcare in Aotearoa/New Zealand, 1940s-2000s. Contemporary Issues in Early Childhood, 8 (2), 133-143.

Meade, A. (1990). Women and children gain a foot in the door. New Zealand Women's Studies Journal, 6 (1).15pp.

Meade, A. (2007) (Ed). Riding the waves. Innovation in early childhood education. Wellington. NZCER Press.

Meade, A. (2010) (Ed). Dispersing waves. Innovations in early childhood education. Wellington. NZCER Press

Meade. A. \& Dalli, C. (1992). Review of the early childhood sector. New Zealand Annual Review of Education, 1, 113-132. 
Meade, A., Robinson, L., Smorti, S., Stuart, M. \& Williamson, J., with others (2012). Early Childhood Teachers' Work in Education and Care Centres: Profiles, patterns and purposes. Wellington. Te Tari PUna Ora o Aotearos, NZ Childcare Association.

Meade, A. \& Podmore, V. (2002). Early Childhood Education Policy co-ordination under the auspices of the Department/Ministry of Education. A case study of New Zealand.UNESCO Early Childhood and Family Policy Series no. 1. March 2002. Paris. UNESCO

Miller, L.K. \& Cable, C. (Eds.), (2008). Professionalism in the early years. Abingdon: Hodder Arnold.

Ministry of Education (2002). Pathways to the Future: Ngā Huarahi Arataki. A ten-year Strategic Plan for Early Childhood Education. Wellington. Ministry of Education. New Zealand.

Ministry of Education (2014). Annual ECE Census Report 2014. http://www.educationcounts.govt.nz/statistics/early-childhood-education/annual-ece$\underline{\text { summary-reports }}$

Mitchell, Linda (2002) 'Currents of change: Early childhood education in 2001'.NZ Annual Review of Education 2001:11, 123-143.Wellington. Victoria University Wellington.

Mooney (2003) 'What it means to be a childminder: work or love?' In Mooney, A., and Statham, J. (Eds).Family Day Care: International Perspectives on Policy, Practice and Quality. London, JKP

Mooney et al. (2003) former childminders survey

Morrison, A. (2014).Census 2013. Statistics on ECE Teachers. Wellington, Ministry of Education.

Moss, P. (2014). Early childhood policy in England 1997-2013: Anatomy of a missed opportunity. International Journal of Early Years Education, 22, 4: 346-358.

NZEI (undated) Influencing policy change through collective action. Institute for Early Childhood Archives, Carmen Dalli collection, Box: Union Reports

New Zealand Educational Institute (1996). Future directions: Early Childhood Education Project Final Report. Wellington. NZEI 
New Zealand Government (1990). Early childhood education qualifications and training. A blueprint for the future.

New Zealand Qualifications Authority (1996). Early childhood education policies. Answers to common questions. Wellington. New Zealand Qualifications Authority.

Nutbrown, C. (2012). Foundations for Quality. The independent review of early education and childcare qualifications. Final Report. London: DfE.

O'Connell, R. (2011) Paperwork, Rotas, words and posters: an anthropological account of come inner London childminders' encounters with professionalization, The Sociological Review, 59, 4, 779 - 802

Rutter, J. (2016) 2016 Childcare Survey. Family and Childcare Trust. http://www.familyandchildcaretrust.org/sites/default/files/Childcare\%20cost $\% 20$ survey\%202 016\%20FINAL\%20VERSION.pdf

Simmons, H., Schimanski, L., McGarva, P., Woodhead, E., Haworth, P., \& Cullen, J. (2006). A reconstruction of roles at Wycliffe Ngā Tamariki Kindergarten COI: Teachers as researchers and researchers as teachers. In A. Meade (Ed). Riding the waves. Innovation in early childhood education. Wellington. NZCER Press.

Simon, A., and Owen, C. (February 2016). Childcare policy: we need decent pay for the workforce and flexibility for parents. IOE BLOG: https://ioelondonblog.wordpress.com/2016/02/04/childcare-policy-we-need-decent-pay-forthe-workforce-and-flexibility-for-parents/ (Retrieved May 4th 2016)

Simon, A., Owen, C., and Hollingworth, K. (2016). Is the 'quality' of preschool childcare, measured by the qualifications and pay of the childcare workforce, improving in Britain? American Journal of Educational Research, 4, 1: 11-17. doi: 10.12691.

Simon, A., Owen, C., Moss, P., Petrie, P., Cameron, C., Potts, P., and Wigfall, V. (2008) Working Together: Volume 1. Secondary Analysis of the Labour Force Survey to Map the Numbers and Characteristics of Occupations Working within Social Care, Childcare, Nursing and Education. DCSF Research Report: TCRU-01-08: http://www.dcsf.gov.uk/rsgateway/DB/RRP/u015432/index.shtml 
Siraj-Blatchford, I. \& Siraj-Blatchford, J. (2010). Improving children's attainment through a better quality of family-based support for early learning. London: Centre for Excellence and Outcomes in Children and Young People's Services.

Smith, A. B. (1988) Education and Care Components in New Zealand Childcare Centres and Kindergartens Australian Journal of Early Childhood, 13 (3) 31-36

Smith, A.B. (2015). Can home-based care offer high quality early childhood education? New Zealand Journal of Educational Studies, 50 (1), 71-85.

States Services Commission (1980). Early Childhood Care and Education: A report of the State Services Commission Working Group. Wellington. State Services Commission St. Johanser, C. (1980). Family day care in New Zealand 1980. Unpublished MA thesis, Victoria University of Wellington, Wellington. New Zealand

Sylva. K., Melhuish, E., Sammons, P., Siraj-Blatchford, I., and Taggart, B. (2004) The Effective Provision of Pre-school Education (EPPE) Project: Final Report (Nottingham: DfES Publications).

Vincent, C. and Ball, S. (2006) Childcare, Choice and Class Practices, London: Routledge Wells, C. (1991). Address to the New Zealnad Free Kindergarten Union Annual Conference, 21 June 1991.

Wells, C. (1999) 'Future Directions: Shaping early childhood policy for the $21^{\text {st }}$ century - A personal perspective', in New Zealand Annual Review of Education 1988:8, 45-60.

Wellington: Victoria University Wellington.

\footnotetext{
' New Zealand is also known as Aotearoa New Zealand to acknowledge its dual Māori and Pakeha (European/other) heritages.

ii The LFS is the largest and most comprehensive source of data on the workforce collecting data from approximately 60,000 UK households per quarter.

iii Data on pay from LFS for the UK has been converted using Purchasing Power Parities so that the income categories are directly comparable to that for the NZ ECE workforce given in the Census. See here for the data tables: https://data.oecd.org/conversion/purchasing-power-parities-ppp.htm . A multiplier (dividing $f$ to NZ for 2013) has been applied to the cash values in $f$ and NZ dollars to arrive at the internationalised figures in this paper. The multiplier for converting $f$ to NZ dollars is 2.0390173; and for NZ dollars to $f$ is 0.4904323 .
} 